\title{
Science, sentiment and territorial chauvinism in the acacia name change debate
}

\author{
Christian A. Kull
}

School of Geography and Environmental Science, Monash University, Clayton, Victoria

christian.kull@monash.edu

Haripriya Rangan

Monash University, Clayton, Victoria

\section{Introduction}

The genus Acacia, as Peter Kershaw has often told us, may be widely present in the landscape, but its pollen is seldom found in any abundance. The pollen grains are heavy and probably not capable of long-distance transport, and even where they dominate the vegetation, their pollen is greatly under-represented. Compounding the problem, Acacia pollen tends to break up into individual units that are difficult to identify. However, as we hope to show in our contribution celebrating Peter's work, the poor representation of acacias in palaeoenvironmental records is more than compensated by its dominating presence in what has been described as one of the longest running, most acrimonious debates in the history of botanical nomenclature (Brummitt 2011).

Few would imagine botanical nomenclature to be a hotbed of passion and intrigue, but the vociferous arguments and machinations of botanists regarding the rightful ownership of the Latin genus name Acacia give an extraordinary insight into the tensions that arise when factors such as aesthetic judgement, political clout and nationalist sentiments dominate the process of scientific classification. After much lobbying and procedural wrangling, on July 16, the last day of the 2005 International Botanical Congress in Vienna, botanists approved a decision to allow an exception to the nomenclatural 'principle of priority' for the acacia genus. With increasing demand by botanists to split apart the massive cosmopolitan and paraphyletic genus into several monophyletic genera, the Vienna decision conserved the name acacia for the members of the new genus from Australia. Normal application of the rules of priority would instead have kept the name acacia for a subset of the trees native to the Americas, Africa 
and Asia. The Vienna decision was unprecedented in the number of species affected and in the amount of public indignation generated across the world. Many professional and amateur botanists, horticulturalists and naturalists, particularly those working in Africa, Asia and Central America (Luckow et al. 2005), were incensed by the decision. In eastern and southern Africa, where the iconic acacias dominate the savannah landscape, popular newspapers such as Nairobi's Sunday Nation announced in a headline "Did you know it is illegal to call this tree acacia? Australia claims exclusive rights to the name" (Githahu 2006).

This essay argues that the ongoing debate and controversy over the acacia genus name is a reflection of a deeper crisis in botanical taxonomy and nomenclature arising from the use of molecular systematics in classification. The splitting of genera and the shifting of species from one genus to another have not only revived older debates in botany regarding classification systems, but also put a great deal of pressure on genus names themselves. We show how the acacia name debate reveals these tensions and contradictions arising from molecular systematics and how rhetoric centred on a variety of non-scientific and non-rational factors, such as aesthetic judgment, sentiments of belonging, territorial chauvinism and politics (lobbying, vote-rigging, etc), came to dominate the procedures of botanical nomenclature.

In the following sections, we offer a brief review of the history of the science and practice of botanical nomenclature, and show how there have been longstanding tensions between folkor place-based classification systems and universal, scientific approaches to plant classification. After explaining the relevant conventions and rules set out by the International Code of Botanical Nomenclature, we describe how the controversy over the ownership of the genus name acacia has developed over the past two decades. We draw on arguments published in scientific journals and the popular media, on interviews with botanists and participant observation of the nomenclature sessions during the 2011 Melbourne IBC to show how sentiments, chauvinisms and egos have dominated the debate and prevented any 'scientific' resolution or compromise emerging from within the conventions of international botanical nomenclature. The essay concludes by arguing that the acacia name controversy and other potential naming crises emerging from molecular systematics can only be resolved by recognising and incorporating the social histories of attachment in plant names in processes of botanical nomenclature.

\title{
What's in a name? Taxonomic debates over systems of classification
}

\author{
Juliet: \\ What's in a name? That which we call a rose \\ By any other name would smell as sweet, \\ So Romeo would, were he not Romeo called, \\ Retain that dear perfection which he owes, \\ Without that title.
}

Romeo and Juliet, Act 2, Scene 2

Notwithstanding Juliet's impetuous claim, the tragic ending of this Shakespearian drama underscores the importance of names and lineages in ordering society and social interactions. Bowker and Star (1999:326) note that 'seemingly purely technical issues like how to name things and how to store data in fact constitute much of human interaction and much of what we come to know as natural'. By naming and classifying things, humans construct a nature that is not just based on objective or observable characteristics, but which also reflects a variety of aesthetic sentiments, cultural traditions and place-based associations and attachments.

Names and categories matter a lot in botanical nomenclature and classifications. People in every part of the world have developed different systems for classifying the plants around them. These 'folk' classifications play a central role in providing a material and emotional sense of 
particular places and regions (Dear 2006). Hence, plant names and their classifications can vary from one place to another, change over time, and vary from one perspective to another. In some cases, a particular plant species may have multiple names within a region depending on how it is used, and in other cases, many different plant species may be called by the same name. But as Gledhill (2008) points out, despite the cultural richness of common names for plants, their immense diversity can make it difficult for those who seek to identify plants according to some kind of larger or 'universal' order so as to compare their characteristics or catalogue their uses.

Going back over two millennia in European history, natural philosophers and botanists sought various principles and criteria that would reveal the hidden order of the rich diversity of plant life in nature. Pavord (2005) traces these efforts back to Theophrastus, a disciple of Aristotle, who attempted to define plants both in philosophical terms of their essential being and in terms of the physical characteristics that could be used to classify them. She notes that his collected works were repackaged in different forms by subsequent Roman scholars, taken up and expanded on by Arab scholars well into the 14th and 15th centuries, and further elaborated on by Italian, Swiss, German and English natural philosophers in the 16th and 17th centuries. Every period of enquiry raised the question of which physical characteristics or behaviours of plants could be used for classification. Scholars of medicine were among the first to draw on folk methods of classifying plants according to their uses as food, dyes, medicines, or poisons, and compiled them in volumes that were known as 'herbals'. Such methods continue to be found today in various herbal reference and guide books for lay people (see, for example, Foster and Johnson 2006), or in classification systems based on the phytochemical properties of plants.

The discipline of taxonomy (derived from Greek, meaning 'arrangement') grew rapidly from the 16th century onwards, alongside the expansion of European maritime exploration, trade and colonialism in the Old and New World. Much of the biota of these regions was unknown to European naturalists. Sixteenth and seventeenth compilations of plants by physicians such as Garcia da Orta for India, Nicolás Monardes for the West Indies, and Cristobal Acosta and Jacobus Bontius for the East Indies described the plants they encountered in terms of their morphological features, such as leaf characteristics, fruit types or flower structure, along with details of their local environments and uses (Cook 2005; Pavord 2005). In doing so, they attempted to combine and adapt local systems of plant classification to similar systems followed in Europe.

As mercantile colonialism gathered pace during the 17th and 18th centuries, European countries were often in direct competition with one another to capture profits from trade in exotic or useful tropical plants that could be cultivated in their colonies. These pressures added to the motivations of naturalists to seek new methods for identifying and classifying plants that could be universally comprehended and applied in different places (Browne 1996). By the end of the 18th century, various naturalists in France, Germany and England had developed some common conventions of naming and ordering plants. Pavord notes that John Ray's Methodus plantarum emendata, published in 1703, provided the six basic rules for classifying plants that ever since have underpinned the discipline of taxonomy: 'Plant names should be changed as little as possible to avoid confusion and mistakes; the characteristics of a group must be clearly defined and not rely on comparisons; characteristics must be obvious and easy to grasp; groups approved by most plantsmen should be preserved; related plants should not be separated; the characteristics used to define should not be unnecessarily increased.' (2005:392)

By the mid 18th century, botany and taxonomy underwent another radical change with the introduction of Carl Linnaeus's classification system. Linnaeus's botany sought, in effect, to develop systems of standardised information exchange that would serve as both a knowledge framework and an instrument for identifying plants of potential economic value to 
European colonisers (Müller-Wille 2005). ${ }^{1}$ In this sense, his approach reflected the new levels of abstraction required by Europe's emerging modern states with their imperial ambitions for control, communication and legibility across their territories (Scott 1998). Linnaeus developed what he called 'artificial' taxonomies of the natural world that reflected the social order and religious ideas of his times (Williams 1980; Dear 2006). God's empire of nature was divided into three kingdoms - vegetable, animal and mineral. Life forms coming under the vegetable and animal kingdoms were hierarchically grouped into classes, orders, families, genus, species and varieties. Linnaeus proposed a binomial system of identification in Latin, with the genus name preceding the special descriptive name for the species (Koerner 1996). He went on to propose a new method, the 'systema sexuale', for grouping plants based on the number, size, arrangement and shape of reproductive organs (stamen and carpels) within in their flowers, and their sexual behaviour (Schiebinger 1996).

The binomial nomenclature system outlined in Linnaeus's Species Plantarum was rapidly adopted during the 18th and 19th centuries as European states competed with each other to launch numerous scientific expeditions for collecting and documenting plants in new lands or in remote parts of their colonies and imperial territories. This was also the period when colonial territories around the world were used for large-scale commercial cultivation of plants as raw materials for burgeoning industrial production in Europe (Brockway 1979; Bonneuil 2002; Parry 2004; Schiebinger 2004; Schiebinger and Swan 2005). However, not all naturalists agreed with Linnaeus's hierarchical ordering or sexual system of classification. Comte de Buffon claimed that Linnaeus's hierarchically organised categories were not properly grounded in understandings of plants and animals in their particular environments. He argued that 'species' was the only category that could be given a clear philosophical definition, i.e. species could be defined on the basis of membership in a common breeding community. In contrast to Linnaean taxonomy, Buffon's approach echoed the methods used in early compilations of plants by Portuguese, Spanish and Dutch physicians in the East and West Indies by focusing on the morphological description of species, their characteristic behaviours and habitats, and their uses to human beings (Cook 2005; Dear 2006). Spanish Creole naturalists in the Americas also opposed the Linnaean system imposed on them by metropolitan botanists, claiming that its abstract mode of classification disregarded important local conditions such as the plant's location, flowering season, climatic requirements and soil characteristics. They asserted that plants needed to be identified and understood biogeographically in terms of their distinctive physical and moral climates, and criticised their imperial overlords for using Linnaean taxonomy to impoverish their colonial subjects by transferring plants to other parts of their territorial empire for economic exploitation (Lafuente and Valverde 2005).

Even though Linnaeus's binomial system of naming plants is now accepted as the starting point for present nomenclature systems, his method of hierarchical ordering and grouping has been routinely criticised for its artificiality, focus on a few selected subsets of characteristics, and lack of contextual references. Pavord observes that '[f]rom Bentham and Hooker in 1862-63, to Cronquist in 1988, eight major systems of plant classification have been proposed in the last hundred years alone' (2005:400). Following the acceptance of Darwin and Wallace's ideas of evolution in nature, evolutionary taxonomy attempted to provide a historical reinterpretation of the Linnaean taxonomic system as a relatively stable and effective format for explaining and predicting genealogical similarity and variations among species. But this was challenged in

$1 \quad$ Müller-Wille (2005) notes that Linnaeus developed his nomenclatural reform and classification system at a time when Sweden had unsuccessfully attempted and later given up its ambitions to gain colonial territories in Africa, Asia, or the New World. However, Linnaeus was inspired by the political-economic ideology that Sweden's prosperity depended on substituting imports with domestic equivalents, or by importing foreign plants and products and subsequently acclimatising them within Swedish territory. 
the 20th century by several botanists who, like many critics of Linnaeus before them, argued against classifications based on similarities of some intuitively determined subset of characters and proposed a phenetic system that determined overall patterns of similarity and dissimilarity between species based on all characteristics. Phenetics, in turn, was accused of being too cumbersome and reliant on subjective choices of statistics for producing measures that give different classifications (Maclaurin and Sterelny 2008). Every proposal for a new system of classification offers different philosophical reasons for grouping species into new genera and for 'lumping' or 'splitting' them into large or small categories. And each of these classification systems then requires new names and combinations as species are moved from one genus to another or regrouped in new genera (Bonneuil 2002; Pavord 2005).

Over the past three decades, however, the emergence and widespread use of DNA analysis has enabled plant scientists to look beyond morphology and work out evolutionary relationships not visible through outward characteristics. Given the long history of debate over 'subjective' criteria for plant classification, DNA-based phylogenetics has been heralded by botanists as offering a more rigorous scientific basis for taxonomy. Molecular systematics or cladistics has become the dominant system used in plant classification (Winston 1999; Soltis et al. 2007; Maclaurin and Sterelny 2008). The system seeks to group plants based on monophyly or evolutionary descent from a common ancestry. Like other reformulations of classification systems, the use of genetic analysis to generate monophyletic trees gives rise to the rearrangement of species in different genera, tribes, sub-families and families.

Molecular systematics represents a monumental shift in both the philosophy and methods of plant classification because it fundamentally challenges the physical observations and experiences that most common or folk systems, as well as traditional botanical systems, have relied on and used. As Yoon (2009) observes, what may appear to most people as a naturally coherent grouping, such as fish, ceases to exist under this new system of classification because not all species show a clear evolutionary relationship. Classification systems based on physical observation may consider lotuses and waterlilies as closely related, but a molecular systematist would argue that they have little in common based on evolutionary relationships, and that lotuses are more related to proteas and plane trees than to waterlilies.

Reclassifications based on monophyly have given rise to substantial upheavals in the ordering and naming of species. Plant genus names are like human surnames, and provide a sense of familiarity and historical continuity of relationships with other species that carry the same genus name. Most people - and this cuts a wide swathe, including amateur naturalists and gardeners, plant breeders, foresters, ecologists and botanists who are used to associating particular Latin binomial names with species that they study, cultivate, use or sell - may find the changes to genus names unnecessary or objectionable and resist reclassification by insisting on retaining the older name. ${ }^{2}$

The current debate over the name acacia illustrates many of the tensions and contradictions that have arisen from taxonomy's move towards abstract genetic-based science. While cladistics relies on the latest scientific advancements and technologies in molecular genetic analysis to justify the splitting of the acacia genus into new genera, the controversy over the resulting name changes reflects a range of concerns that some taxonomists regard as subjective and unscientific. These include aesthetics tastes, sensibility of place, territorial chauvinism and personal and institutional politics. In the following sections, we outline the rules of botanical nomenclature, followed by a description of the genesis and evolution of the acacia name war, and analysis of

$2 \quad$ As one botanist pointed out, 'There is a whole other debate and gnashing of teeth whenever botanists change names. We are the villains to many horticulturalists for example. Just listen to any gardening program or TV garden show when there is a difficult to pronounce botanical name or if a taxonomic change has been made. We encounter this resistance all the time' (anon. interview 2009). 
the arguments marshalled on either side of the debate.

\section{Nomenclatural rules and conventions}

Taxonomists usually follow a set of standardised rules in naming plants (Bailey 1933; Winston 1999; Spencer et al. 2007). These rules are recorded in a central register called the International Code of Botanical Nomenclature, which is maintained by the International Association for Plant Taxonomy. Each edition, which is published after the meetings of the International Botanical Congress in a series called Regnum Vegetabile, provides an update of these rules and decisions of changes to nomenclature that were proposed and endorsed by the Congress. For instance, the 'Vienna code', which was published in the series Regnum Vegetabile (Vol. 146, 2006), includes nomenclature decisions from the 2005 Congress.

The fundamental rule of nomenclature is that the first person to scientifically describe a species has the privilege of naming it. For plants, this involves placing a specimen in a herbarium (the 'type' specimen) and publishing a technical description of it (Gledhill 2008). The epithet given to a species may reflect distinctive physical characteristics - like Acacia grandifolia (for large leaves) and $A$. microsperma (for small seeds), and may also commemorate people, places and cultures. For example, Acacia baileyana memorialises the Australian botanist F.M. Bailey, Acacia farnesiana is named after the famous garden estate of Cardinal Farnese in Rome, and Acacia koa honours the indigenous Hawaiian name of the tree.

However, if a species has been officially described more than once with different names, or if two species described separately are later determined to be one and the same, then the rule specifies that the oldest name should be used. This is known as the rule of priority. For example, the black wattle from southeastern Australia was known for much of the 19th and early 20th centuries by names such as Acacia decurrens var. mollis or A. mollissima, based on specimens described in European herbaria (Brenan and Melville 1960). Now it is named after an American naturalist, Edgar A. Mearns, who collected naturalised specimens in Kenya between Thika and Nairobi while on a hunting and scientific safari with Theodore Roosevelt in 1909. Mearns, best known as an ornithologist, died in 1916, unable to process his findings (Richmond 1918), but his African botanical collection made its way to the National Botanical Gardens in Brussels. Here, the Director, Émile de Wildeman, published a description of the specimen in 1925 in Plantae Bequaertianae, honouring Mearns in the name of the plant he believed to be a new African species, Acacia mearnsii (de Wildeman 1925). De Wildeman's species description, and hence Mearns's name, later achieved taxonomic priority because the older scientific names for the black wattle were found to be invalid. ${ }^{3}$ Hence $A$. mearnsii was the oldest legitimate name available, and thus it took priority. Brenan and Melville (1960:38) lamented that this acacia from Australia 'must bear the misconceived and not especially relevant name mearnsii'.

Following on from this rule, the next is that the name of a genus should be taken from the name given to one of its member species that has been designated as the 'type' representing the genus. The type species is designated by a botanist when publishing his or her conception and description of a genus; there are no rules as to which must be chosen, but in practice the type species is usually one that is well-known, is widespread, or holds an old, established name. For example, the type for the genus acacia is the widely known Afro-Asiatic thorn

3 Specifically, the name $A$. mollissima was rendered inappropriate as it was found that the herbarium specimen it described (its 'type') was actually $A$. pubescens. As far as $A$. decurrens var. mollis, this name is still technically legitimate but most botanists consider the black wattle a distinct species from $A$. decurrens (green wattle), not a variety (Brenan and Melville 1960). 
tree, $A$. nilotica, described in 1753 by Linnæus. ${ }^{4}$ As botanists examined samples of Australian wattles, they included them in the already existing acacia genus because of their morphological similarities to known African and American acacias. In contrast, when l'Héritier described gum tree specimens, he created a new genus Eucalyptus based on its uniqueness (Brooker and Kleinig 2007).

The above two rules would be sufficient were it not for the fact that the science of classifying living things is a difficult and continually evolving endeavour. On the one hand, obscure early publications on particular plants are sometimes rediscovered after alternative names have become commonly used. On the other hand, developments in taxonomy can lead researchers to propose different ways of grouping plants into species and genera. Both factors can contribute to a cascading effect of name changes. This then leads to a third rule of nomenclature called 'conservation'.

Conservation is a special clause in the rules of nomenclature - an infrequently used exception to the rules of priority - that is used to protect certain botanical names (typically wellknown ones) from being changed due to new developments in taxonomic science or due to the technicalities of botanical nomenclature. For example, in 1980 it was discovered that the widely used Latin name for wheat, Triticum aestivum, would have to change to Triticum hybernum. These two species were described separately by Linnaeus in 1753, but later became seen as just two varieties of a single species, widely called T. aestivum. However, as was rediscovered in 1980, the earliest person to merge the species had given the name T. hybernum to the combined species, and by strict application of the rule of botanical nomenclature, this name would achieve priority. In order to avoid changing the widely used botanical name of wheat, the name Triticum aestivum was 'conserved' at the 1987 International Botanical Congress in Berlin (Hanelt et al. 1983).

Technically speaking, 'conservation' applies to the name given to a particular herbarium specimen. That is, a particular name is permanently attached to a particular specimen, normally the 'type' specimen that defines a species and perhaps its genus. In cases where one conserves the name of a specimen that was previously not the type specimen, it is referred to as 'retypification'.

According to the rules, the decision to conserve must be justified by establishing that it would serve the interests of maintaining nomenclatural stability and avoid disadvantageous name changes. Cases for conservation and rejection are made in the journal Taxon, and are considered by specialist committees of the International Botanical Congress's Nomenclature Section before being approved by the congress as a whole.

A final convention in botanical nomenclature is that new species names resulting from the above procedures do not officially exist until they are published as 'combinations', that is, until a scientific publication appears with the combined new genus and species name. According to one plant taxonomist (anon. interview 2007), some botanists are hesitant to be the first to publish an unpopular new name, partly out of a sense of not wanting to step on another botanist's turf, while others might see it as an opportunity to 'get their names on combinations'. ${ }^{5}$ The peerreview process for scientific literature may serve different roles in these situations by either

$4 \quad$ The first specimen described was named Mimosa scorpioides by Linnaeus but is now universally accepted as a synonym of Acacia nilotica. Botanist Philip Miller formally adopted the genus name Acacia (already in wide use) in 1754, hence its notation as 'Acacia Mill'. However, it was only in the 1800s that Acacia became widely accepted, following George Bentham's broad definition of Acacia (for details, see Maslin et al. 2003a; Orchard and Maslin 2003).

5 This statement refers to the convention among botanists where the first published source of a new combination must be cited when establishing the 'authority' of a plant's name in scientific publications. 
retarding the appearance of unpopular new combinations or enforcing their use. ${ }^{6}$ It should also be noted that one may continue to use old names if one justifies the taxonomic reasons for doing so. For instance, if one insists that the acacia genus does not need to be split, one can continue using the name acacia in its broad sense (see Pedley 2004; Smith et al. 2006; Robin 2007).

\section{The acacia genus, the Battle of Vienna and beyond}

The modern acacia genus is a broad classification that emerged in the 1840s through the efforts of botanist George Bentham (Ross 1980; Maslin et al. 2003b). Thanks to his position at the Royal Botanic Gardens in Kew, Bentham was exposed to plants from around the world (Bentham 1842; Bentham and Mueller 1864). The broad genus he defined now includes more than 1300 species worldwide, of which approximately 1000 are found in Australia. It is classified in the Mimosoideae subfamily of the Fabaceae family, better known as the legume family for its seed pods.

Over the past few decades, botanists have argued that the acacia genus was too massive and not monophyletic, and hence needed to be split along the lines of sub-genera identified by Vassal (1972). Molecular genetic analysis added weight to these claims, showing, for example, how Australian wattles are more closely related to the tribe Ingeae (which includes the genera Albizia, Calliandra and Paraserianthes) than to other acacia sub-groups typified by Acacia nilotica or Acacia senegal (Figure 1; Clarke et al. 2000; Murphy et al. 2003; Jobson and Luckow 2007; Brown et al. 2008; Murphy 2008). Les Pedley (1986), of the Queensland Herbarium, first proposed a three-way split, which was later modified to include two minor new genera from the Americas (Figure 2; Figure 3). Because the type species for the old, broad genus was Acacia nilotica, the name Acacia was to be given to the subset of the old genus that contained $A$. nilotica and some 160 other pan-tropical acacias. This left the two new genera in need of names. Based on the rules of priority, Pedley recovered two genus names from the dustbin of botanical history for the remaining species: Senegalia, which applied to 200 tree species mainly from Africa, and Racosperma, for the roughly 1000 species mostly found in Australia and nearby islands. In his proposal, Pedley published 33 combinations for Racosperma and two for Senegalia, including Racosperma auriculiforme (for Acacia auriculiformis), Racosperma mearnsii (for Acacia mearnsii), and Racosperma koa (for Acacia koa).

The genus names suggested in Pedley's original proposal were adopted in very few publications, an exception being the Flora of New Zealand (Webb et al.1988), which used these to describe a number of introduced Australian wattles as Racosperma. Most botanists resisted using the new name, arguing that further evidence was needed from molecular research, but also out of some discomfort about the implications for name changes (Maslin et al. 2003a, b; Murphy 2008).

Even as molecular evidence accumulated to back Pedley's proposed division of the genus, many botanists remained reluctant to accept the split. The main reason, it so happened, was the ungainly name Racosperma. Some called it an 'abomination' in comparison to the more elegant and euphonic name acacia (Woodford 2002; Pedley 2004:4). Some South African botanists gloated over the appropriateness of a harsh-sounding name for species that had been declared 'alien invasive weeds'. ${ }^{7}$ Montgomery (2006) wrote in South African Gardening:

\footnotetext{
$6 \quad$ This was our personal experience with a previous publication in an ecological journal. A reviewer who had taken the Vienna decision on board wrote, 'The authors have to take into account that the genus Acacia now only refers to Australian species. Other species have now been assigned to other genera.' See also Boy (2005:27).

$7 \quad$ In a similar vein, an article in the South African magazine Veld and Flora plays on trans-Indian Ocean rivalries when titling an article about efforts to control invasive $A$. pycnantha 'Golden wattle loses its lustre'. The first line mentions the tree's status as Australia's floral emblem; much of the rest describes efforts to control it by introducing a gall wasp from its home range (Hoffmann 2001:58).
} 
rest of Mimosoideae

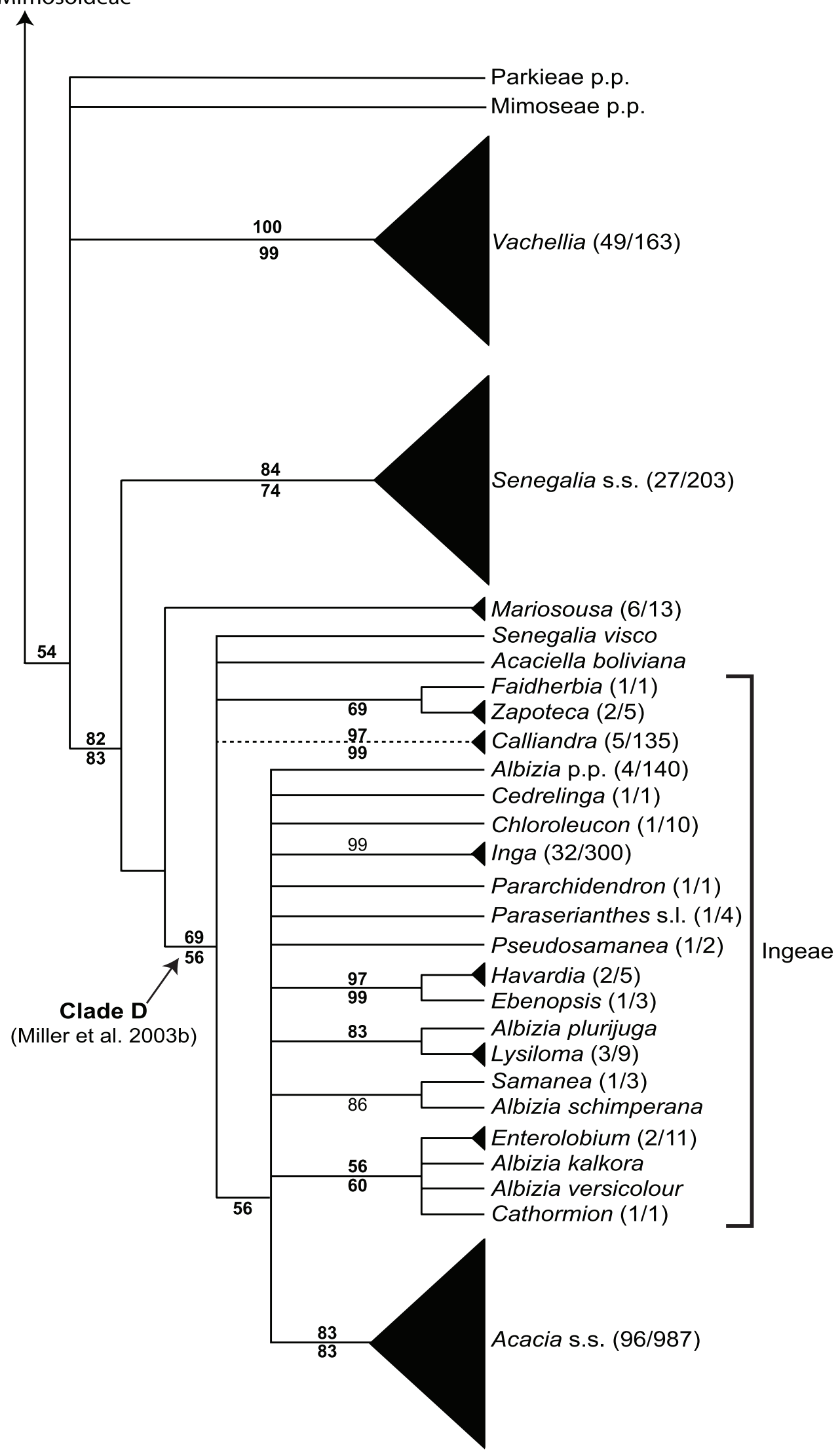

Figure 1. A 'genetic family tree' created from DNA analysis of different acacia species and nearby genera. This tree demonstrates how different sections of the old acacia genus are closer to other species in the tribe Ingeae than to each other. Source: first published in Brown et al. (2008:741), reproduced with permission of authors. 


\section{Acacia sens. lat.}

1. subgenus Phyllodineae

\section{Racosperma}

3. Acacia sens. str.

(following new type A pennineris)

$\sim 1000$ spp.

Australia and adjacent islands

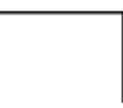

1. subgenus Aculeiferum

2. Senegalia sens. lat
1. subgenus Acacia

2. Acacia sens. str.

(following old type A. nilotica)

3. Vachellia

pantropica

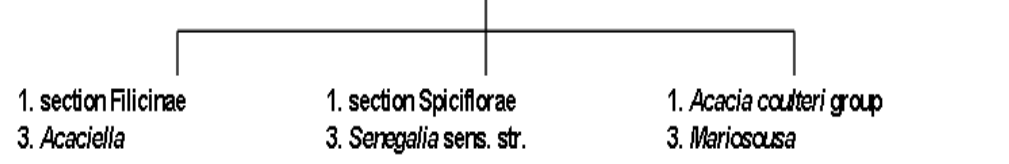

$\begin{array}{lll}\sim 15 \mathrm{spp} . & \sim 200 \mathrm{spp} . & \sim 13 \mathrm{spp} . \\ \text { Americas } & \text { pantropical } & \text { Americas }\end{array}$

1. Former subgenus or section name.

2. Proposed new genus name according to Pedley (1986).

3. Proposed new genus name according to Maslin (2003)

Figure 2. The different names of the proposed divisions of the acacia genus. Source: based on Maslin et al. 2003a.

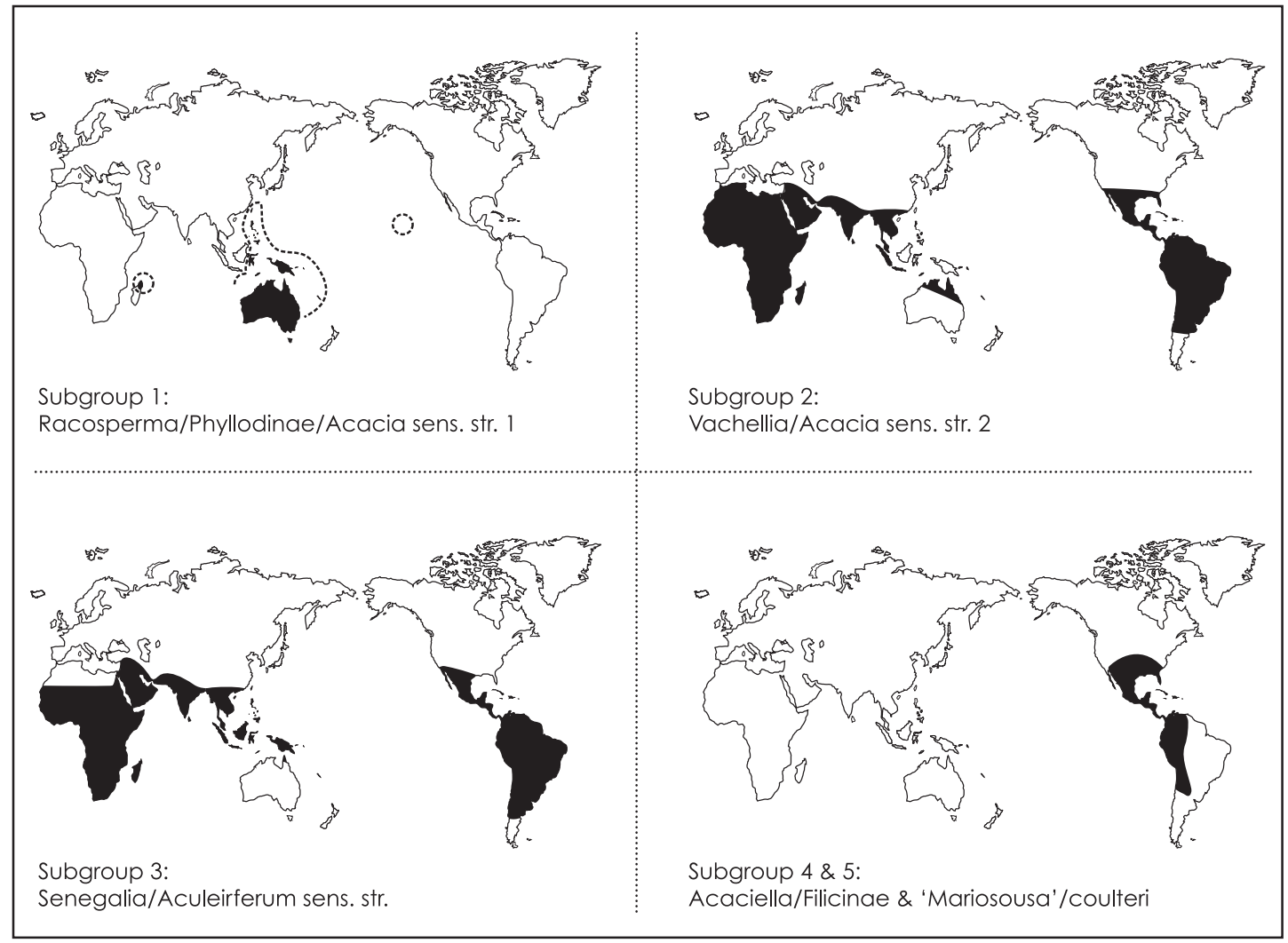

Figure 3. The geography of acacia's taxonomic revision: native distribution of different acacia subgroups. Source: based on Maslin et al. 2003a. 
It was further decided that Australian acacias should fall under the genus Racosperma. The local botanical community gave a chuckle. Twelve Australian acacias (wattles) including the black wattle (Acacia mearnsii) are designated Category 2 invasive alien weeds in this country. To give our unwanted cousins a new name (Racosperma mearnsii) was viewed locally as positive. (Montgomery 2006)

In contrast, Pedley's proposal to rename a different set of acacias Senegalia did not meet with the same resistance because the name sounded reasonably mellifluous and referred to a geographical area where the genus was widespread (interview anon. 2009).

Resistance to the use of the genus name Racosperma inspired Bruce Maslin, of the Western Australian Herbarium, together with Tony Orchard, of the government's Australian Biological Resources Study (ABRS), to propose an alternative solution that would maintain the familiar moniker acacia for the Australian species. Orchard and Maslin's (2003) proposal called for a retypification of the acacia genus. Specifically, the proposal called for the conservation of the name Acacia penninervis (commonly known as the hickory wattle), implying that it would become the type specimen for the genus that includes it. This species was chosen because it already served as the type for the Acacia sub-genus Phyllodineae. As a result, the consequences of splitting the acacia genus would be different: the name Acacia would apply to the mainly Australian part of the genus, while the group including the former type species, A. nilotica, would take on the oldest valid alternative name, Vachellia. Senegalia was to remain unaffected (see Figure 2).

While the Committee for Spermatophyta (a specialist committee of the Nomenclature Section of the IBC) was deliberating on Orchard and Maslin's proposal, Pedley (2003) published some 800 combinations for Racosperma, allegedly in reaction to the claim that very few Racosperma combinations had been made. While the secretary of the committee commented on the 'surprising' nature of Pedley's action (Brummitt 2004:828), some botanists regarded it as a gauntlet thrown down to challenge Orchard and Maslin's proposal. By this point, the issue was already entwined with egos and the lobbying of key individuals (interviews anon. 2011).

The case for retypification was debated at the 17 th International Botanical Congress, held in Vienna in 2005. On 16th July, the last day of the Congress, the Nomenclature Section voted on the recommendation of specialist committees to change the type species of acacia from $A$. nilotica to $A$. penninervis. Following the complex procedural rules of nomenclature revision (Smith et al. 2006; van Rijckevorsel 2006; Moore 2007; Glazewski and Rumble 2009; McNeil and Turland 2010), a 60\% supermajority vote was required to overturn this recommendation. The headings 'Africa' and 'Australia' were penned on a whiteboard as the vote was prepared, accentuating the geographic symbolism (Moore 2007:114). When votes were tallied, a majority (54.9\%) of the Nomenclature Section members had voted against the recommendation, but this was short of the $60 \%$ supermajority requirement. Hence, the recommendation for retypification was allowed to pass and be ratified by the plenary session.

The result of the vote meant that the Australian plants would retain the name Acacia following a split of the genus, and many of the non-Australian species would be renamed Vachellia. Shortly after the decision, new combinations were published for several American species under the name Vachellia (Seigler and Ebinger 2006) as well as Senegalia (e.g. Seigler et al. 2006), and the names have begun to appear in Latin American floras (Maslin 2011).

The botanic community was sharply split, with one faction, described as 'the tropical botanist community', saying it was 'immensely disappointed' by the decision (Smith et al. 2006:225), a 
sentiment also held by Racosperma promoter, Les Pedley (2004). ${ }^{8}$ The Vienna decision touched a sensitive nerve of botanists in eastern and southern Africa, who were outraged by the outcome. 'So we won but we lost,' said Dr Siro Masinde, Director of the East African Herbarium in Nairobi, referring to the supermajority needed to overturn the recommendation. ${ }^{9}$ Numerous members of the biological, forestry and environmental communities in South Africa expressed their indignation over the naming coup (interviews 2007). Opposition was also voiced by the Chairperson of the Botanical Society of Namibia (Hoffman 2006). Veld and Flora, the Journal of the South African Botanical Society, was overwhelmed by letters of protest. ${ }^{10}$ Likewise, Swara, the journal of the Kenya-based East African Wild Life Society, carried a detailed analysis, with the opening proclamation:

It is official: Africa no longer has any indigenous Acacias. The continent's magnificent, archetypal thorn trees - which, as Acacias, have long been universally synonymous with Africa's great savannahs and bush lands - have been formally stripped of their names (Boy 2005:25).

Media reports further sensationalised the news. In addition to the Sunday Nation article (mentioned in our introduction), the Kruger Park Times ran an article, 'Africa to lose all its acacias', and the South African Gardening magazine opined 'Brand Acacia goes to Australia' (Montgomery 2006). In Australia, in contrast, the mood was jubilant. The story appeared on the national broadcaster ABC's popular radio program Australia All Over. The Sydney Morning Herald declared:

September 1 has many names. Some welcome it as spring's dawn, a time to celebrate nature's renewal. For others it's Wattle Day. But it will never be Racosperma Day. (Macey 2005)

In the aftermath of the Vienna decision, the opponents of retypification complained about 'the way the Australians ... conned the Vienna conference' (Cameron 2006:51). Moore (2007:109) called it 'an attempt at minority rule' and blamed inconsistent and confusing implementation of procedural rules (see also Boy 2005; Smith et al. 2006; van Rijckevorsel 2006; Moore et al. 2010, 2011). Moore (2007: 112) noted that African and South American taxonomists - who formed the bulk of the opposition - were under-represented in the debate because of their relatively small presence at the Vienna meeting due to limited budgets for international travel. In contrast, he claimed, the pro-retypification lobby, which had 'substantial backing from Australian botanists', was prominent in meetings and in notice-board postings (see also Smith et al.2006:225). African representatives accused Australian botanists of stacking the debate by mobilising various resources, including funding delegates to attend the meeting and vote in their favour. ${ }^{11}$ The editor-in-chief of South African Gardening commented on the

8 According to one botanist, 'there were actually many Australian botanists against the proposal (see Luckow et al. 2005 for names, including Lyn Craven and Mike Crisp). On the other side, many international botanists were supporting the Australian Acacia proposal... It was not really divided along geographical or political lines in my opinion, more on whether people agreed or disagreed with the arguments for application of the conservation of names measures in the ICBN. Some institutions had their own internal votes before Vienna and others left the decision up to a single delegate to cast their votes. I think the media and subsequent argument has skewed that sense of sentiment and politics' (interview 2009).

9 Interview 2006. Masinde, along with most African botanists, voted by proxy.

10 A page of letters was printed in the March 2006 issue (p. 51). According to the subsequent issue, these letters were 'the tip of the iceberg in responses' (Veld and Flora, June 2006, p. 72); this issue printed four more letters (p. 73).

11 Interview, Dr. Siro Masinde, Nairobi, September 28, 2006 (see also Boy 2005). Such perceptions were also described by Dr. Najma Dharani, author of Field Guide to Acacias of East Africa (interview Nairobi 2006), and in Moore (2007) and Smith et al. (2006). 
Vienna decision saying: 'It is an extraordinary tale of botanical intrigue... a team of Australian botanists pulled off the world's greatest branding coup... with ferocious public support, massive documentation, and a superb public relations machinery.' Referring to the sporting rivalry between the two countries (in cricket and rugby), she added: 'the South Africans underestimated the Australians (again!)' (Montgomery 2006).

O'Neill (2007), an Australian botanist, hailed the Vienna decision with relief for having escaped the ugly genus name Racosperma: 'Had the proposal failed, Australia's national floral emblem, the golden wattle, might now be Racospermum pycnantha' [sic]. The unstated assumption for the supporters of retypification was that by celebrating the wattle as a national symbol, Australia had gained the right to retain the euphonic name Acacia for its species.

In the run-up to the following International Botanical Congress (held in July 2011 in Melbourne, Australia) these arguments and tensions resurfaced, many of them focused on perceived injustices in the procedures behind the Vienna decision. ${ }^{12}$ Gerry Moore, of New York's Brooklyn Botanic Garden, led the charge in seeking to annul the decision made in Vienna (Moore et al. 2010, 2011). A website was dedicated to documenting support (www.acaciavote. com, last accessed 28 July 2011). Others defended the Vienna decision (Thiele et al. 2011). In what might be interpreted as a rearguard action, Bruce Maslin encouraged members of the Australian Systematic Botany Society and of the 50-year-old Acacia Study Group (member of the Association of Societies for Growing Australian Plants) to attend the Melbourne IBC and vote to maintain the Vienna decision. Some botanists outlined new, compromise, solutions to rename acacia (Brummitt 2010, 2011; Turland 2011; Table 1). Dick Brummitt, of Kew Herbarium, the ex-Chair of the Committee for Spermatophyta, said that while the Vienna decision was sound, the unprecedented uproar (and numbers of species affected) needed an unorthodox solution. In the event, the highly charged sessions of the Nomenclature Section of the Melbourne IBC did not overturn the Vienna decision nor accept any of the compromise proposals (Smith 2011). ${ }^{13}$ As Gideon Smith, of South Africa's National Biodiversity Institute, remarked during the deliberations, the issue of which genus has the right to retain the name acacia will remain divisive and the controversy is unlikely to go away.

\section{Analysing the arguments: From rational criteria to rhetoric and politics}

The formal rules of botanical nomenclature are, in principle, set up to alleviate the tensions over names caused by the evolving science of taxonomy. According to L.H. Bailey, author of How Plants Get Their Names (1933), scientific decisions over taxonomy come first, and any consequences for names follow:

The naming of plants under rules of nomenclature is an effort to tell the truth. Its purpose is not to serve the convenience of those who sell plants or write labels or edit books; it is not commercial. Serving the truth it thereby serves everybody. (p. 39)

\footnotetext{
12 B. Maslin and D. Brummitt, pers. comm. 2011, and email from Bill Aitcheson, leader of the Acacia Study Group, 10 May 2011. See also Maslin (2011) and acacia name change blog postings at christiankull.net (last accessed 28 July 2011). 13 The meeting started with a contentious discussion of the $60 \%$ supermajority rule. It then ratified the Vienna Code as printed using a card vote (373 yes, 172 no). The large 'no' vote reflected opposition to acacia retypification. Brummitt's compromise proposal was considered both unconventional and unacceptable; Turland's compromise proposal to create Protoacacia and Austroacacia (Table 1) was seen as a possible way out, but the name Protoacacia was questioned because it seemed to imply some evolutionary meaning. An alternative proposal by Paul van Rijckevorsel (Utrecht) accepted Acacia for the Australian species but sought a different name to replace Vachellia, tentatively Africacia, but this was critiqued, as the distribution of Vachellia includes Asia and Latin America (never mind that in this proposal 'victory' would remain with the retypification proponents). Brian Schrire (Kew) suggested, in the spirit of getting a compromise, a different alteration of Turland's proposal, replacing Protoacacia with Acanthacacia (representing 'thorns'). Turland's proposal (with Schrire's modifications) was, however, rejected by a $70 \%$ majority.
} 
Table 1. The naming consequences of different proposals to the IBC.

\begin{tabular}{|c|c|c|c|c|c|}
\hline $\begin{array}{l}\text { Sub-genera of old } \\
\text { inclusive genus } \\
\text { Acacio }\end{array}$ & $\begin{array}{l}\text { Nomenclatureal } \\
\text { consequence } \\
\text { of Pedley } \\
\text { (1986) and later } \\
\text { research }\end{array}$ & $\begin{array}{l}\text { Proposal by } \\
\text { Orchard and } \\
\text { Maslin (2003) } \\
\text { approved at } \\
\text { Vienna IBC in } \\
2005 ; \text { contested } \\
\text { by Moore et al. } \\
(2010,2011)\end{array}$ & $\begin{array}{l}\text { Proposed } \\
\text { compromise by } \\
\text { Brummitt (2010) }\end{array}$ & $\begin{array}{l}\text { Proposed } \\
\text { compromise } \\
\text { by Turland } \\
\text { (2011) (includes } \\
\text { keeping use of } \\
\text { Acacia for old, } \\
\text { inclusive genus) }\end{array}$ & $\begin{array}{l}\text { Result of } \\
\text { Melbourne IBC in } \\
2011\end{array}$ \\
\hline $\begin{array}{l}\text { subgenus } \\
\text { Phyllodinae (>1000 } \\
\text { species of wattles } \\
\text { in and around } \\
\text { Australia - typified } \\
\text { by } A \text {. penninervis) }\end{array}$ & Rocosperma & Acacio & $\begin{array}{l}\text { Acacia for general } \\
\text { use } \\
\text { Acacia } \\
\text { (Rocosperma) for } \\
\text { specialist use }\end{array}$ & Australacacia & Acocia \\
\hline $\begin{array}{l}\text { subgenus Acacia } \\
\text { (ca. } 160 \text { species } \\
\text { of thorn trees in } \\
\text { Africa, Asia, Latin } \\
\text { America - typified } \\
\text { by A. nilotica) }\end{array}$ & Acacio & Vochellia & $\begin{array}{l}\text { Acacia for general } \\
\text { use } \\
\text { Acacia (Vachellia) } \\
\text { for specialist use }\end{array}$ & $\begin{array}{l}\text { Protoacacia } \\
\text { (amended at } \\
\text { Melbourne } \\
\text { IBC } 2011 \text { to } \\
\text { Africacacia then } \\
\text { Acanthacacia) }\end{array}$ & Vachellia \\
\hline
\end{tabular}

and, unaffected by the conflict, but not to be forgotten....

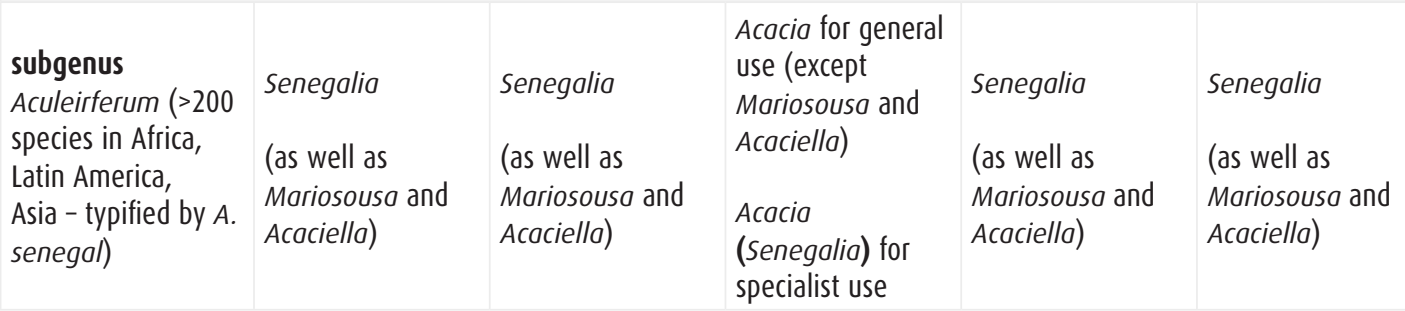

Bailey's views continue to be espoused by many professional botanists. As one remarked, 'Botanists like me, in the end, typically just want the rules applied strictly. It is the science that matters, and the rules, and names, follow' (interview anon. 2007). Yet the existence of procedures for the 'conservation' of names is an acknowledgement that inconvenience, even tension, may arise from strictly following the rules.

The official case for conservation of a name is meant to rest on objective evidence that such an action would minimise disruption and stabilise nomenclature for well-known, widely used names. In the acacia debate, both sides formally argued their case in the journal Taxon using arguments about numbers of name changes, the magnitude of inconvenience and the economic value of these well-known species. These rational arguments, however, were supplemented by particular kinds of rhetoric - centred on aesthetic judgements, place-based sentiments and feelings over process and politics - to bolster the claims for which genus should rightfully bear the name acacia. Below, we review both the more objective arguments, as well as the rhetoric and politics in the preparatory technical documents prepared before the Vienna meeting and in the flurry of commentaries and editorials that emerged afterwards, up through the re-hashing of the issue at Melbourne.

The formal case for retypification was laid out by Orchard and Maslin $(2003,2005)$. First, they argued that a change to Racosperma would create a high level of inconvenience. They pointed out that acacias were so dominant in the flora of Australia that fully $6 \%$ of all plant 
species would need to change to Racosperma unless retypification took place. They pointed out that 1274 species would be subject to name changes were the acacia genus split into five new genera without retypification (Figure 2). By changing the type species from Acacia nilotica to $A$. penninervis, the number of name changes would be reduced to 392 species (231 names, for the new genera Senegalia, Acaciella and Mariosousa, would have to change either way). By retaining the genus Acacia for the more numerous Australian species, they argued that potential confusion and disruption would be minimised in terms of relabelling work for herbaria, nature walks, legislation, textbooks and databases around the world. They also made an issue of the grammatical impacts of using Racosperma: due to this word's neuter gender, its use would necessitate spelling changes to numerous species names, replacing the suffix $-a$ with $-u m$, such as Acacia pycnantha to Racosperma pycnanthum, or Acacia aneura to Racosperma aneurum (Maslin and Orchard 2004a). The retypification lobby less convincingly added that it would be easier to have Africa, Asia and the Americas rename (nearly) all their acacias than only renaming some of them.

The opponents of retypification made their official case in an article co-authored by 37 botanists from around the world, with the central argument that 'in a case as contentious and hotly debated as this one... simple priority should prevail' (Luckow et al. 2005:515; see also Smith et al. 2006). They claimed that the case for retypification based on the magnitude of inconvenience was made on spurious grounds, and that instead of counting numbers of species, it was necessary to count the number of countries or the total human population in the zones affected by retypification of the genus. They pointed out that adopting the name Racosperma would only affect Australia's 20-odd million people and people living in a few small Pacific islands. In contrast, retypification of the acacia genus to represent the Australian species would force name changes across several continents with a combined population of more than two billion people, and, as a result (among other things), necessitate updates to many more national floras and databases.

A second set of arguments focused on economic disruption. Retypification proponents pointed out that the commercial importance of Australian species far outweighs that of the rest. There are more than two million hectares of Australian acacia plantations outside Australia, with many species widely known in industrial forestry, in agroforestry and as ornamentals (Midgley and Turnbull 2003). They argued that 'large scale name changes would not only burden the above industries and activities with large overhead costs, but would also take considerable time and effort' (Maslin et al. 2003a:13).

In response, the critics of retypification accused the proponents of trying to monopolise the name 'Acacia for a developed country at the expense of widespread changes across numerous developing countries' that could least afford the cost of such name changes (Luckow et al. 2005:516; see also Boy 2005; Moore 2006b). They noted that non-Australian acacias had substantial economic importance both in terms of numbers of people using the trees for various subsistence, medicinal and commercial uses, and in terms of their symbolic value for the tourism sector in eastern and southern Africa (Luckow et al. 2005). Moore (2006b:72) pointed out that:

the Acacias are charismatic trees of the African savanna..., their silhouettes against the setting sun a savanna icon. It is a brand name, as valuable as champagne, and one that serves as the logo for one of Africa's largest banks. It is a key marketing attraction for the entire African tourist industry.

References to symbolic value and iconic status indicate that the arguments surpassed mere discussions of nomenclatural stability and minimisation of disruption. Other rhetorical 
arguments were made to bolster the claims. For example, the opponents of retypification asserted that since the Greek root word for acacia is akis, meaning thorn, it was ludicrous to retain this genus name for the largely thornless acacias of Australia (Moore 2006b). They also evoked the usage of common names, pointing out that Africa's thorny acacias are widely recognised and known as 'acacia' the world over, whereas the Australian acacias are commonly known as 'mimosas' in Europe and as 'wattles' in Australia. ${ }^{14}$ Why, they asked, should one conserve the genus name Acacia for the Australian species when few refer to them by that name? Instead, they pointed out, it would be simpler to use the genus name Racosperma for nearly all the native species in Australia and neighbouring countries (Pedley 2004; Luckow et al. 2005; Boy 2005; Moore 2006b).

Sentiments of place, merged at times with national or continental chauvinism, were also widely called on to justify both positions. Orchard and Maslin (2005) noted that acacia flowers were a prominent element of the winter and springtime landscapes of the populated parts of Australia, when their brilliant yellow blossoms provided spectacular splashes of colour against the rich green hues in pastures and eucalyptus forests. They pointed to the iconic status of wattles for the nation of Australia. As Libby Robin and Jane Carruthers have documented (Robin 2002, 2007, 2008; Carruthers and Robin 2009; Carruthers et al. 2011), the wattle was crowned as the floral symbol for the young federation of Australia that was seeking to establish its distinctive identity in relation to Britain. According to Robin (2008:3), wattles were seen to symbolise 'a fair and equal Australia' because of their widespread presence and distribution across the whole continent. The golden wattle, Acacia pycnantha, was finally formally named the national floral emblem in 1988 during bicentennial celebrations of European settlement. It appears on the national coat of arms (Figure 4), in the design of the Order of Australia medals, and in the green and gold colours of the national sports teams. The first day of spring (1st September) in Australia is called Wattle Day, when politicians pin sprigs of wattle bloom on their lapels (as they also did in October 2002 to commemorate the Australian victims of the terrorist bombings in Bali). All of these factors, proponents of retypification asserted, were additional reasons to justify keeping the Latin name Acacia for Australian species.

Their opponents made similar arguments. Botswana's Andy Moore (2006a:51) noted that acacias are 'the icons of the savannah' and rhetorically stated: 'Put out a picture of an acacia silhouette against a setting sun, and ask anyone to say whether this makes them think of Africa, Australia, or Antarctica.' Similar assertions claiming the African-ness of acacia were made in Swara (Boy 2005) and in letters to Veld and Flora (Cameron 2006:51). As the exchanges between the two sides grew increasingly vitriolic, Pedley (2004) complained:

the rest of the world will not only have to abandon the name Acacia, but will have to accept transfers of species to at least two genera, both with unfamiliar names. The lovely flat-topped trees of the African veldt will be Acacia no more, but Vachellia. About an equal number of African species will go to Senegalia. The situation in Asia is similar... the situation in the Americas is worse. (Pedley 2004:4)

By the time the Vienna meeting approached, the so-called rational arguments and application of rules for retypification of acacia had disintegrated into a slanging match over its iconic status in Africa and Australia and its association with a sense of national or continental identity. The secretary of the Committee for Spermatophyta accused both sides of chauvinism (Brummitt 2004). Pedley (2004:4) stated it bluntly, claiming that:

14 Continental Europeans use the common name 'acacia' to refer to an unrelated American tree (Robinia pseudoacacia). Acacias introduced to Australia tend not to be given the common name 'wattle': Acacia nilotica goes by the common name 'prickly acacia', while $A$. farnesiana is 'mimosa bush'. 


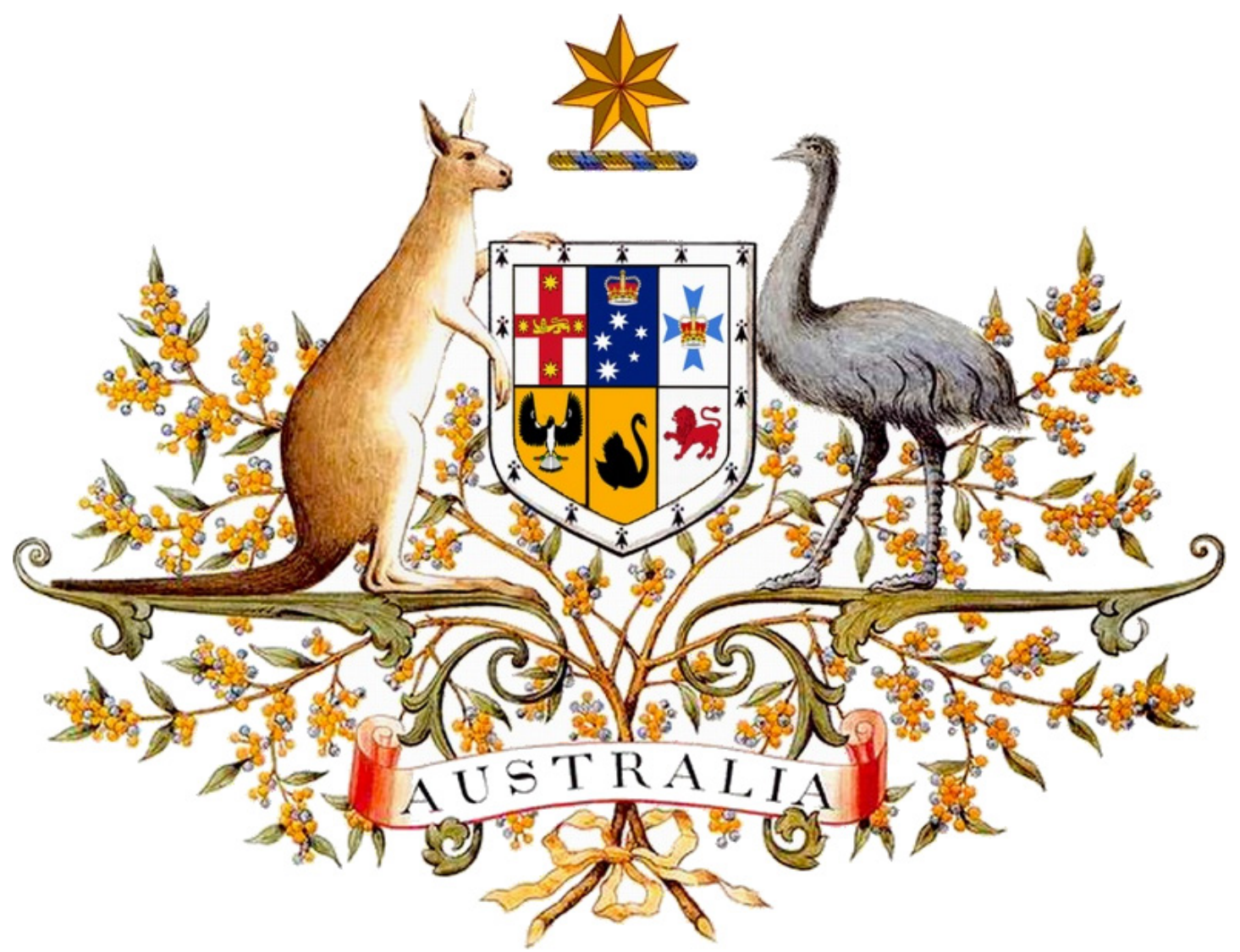

Figure 4. Australia's current '1912' coat of arms, with stylised golden wattle Acacia pycnantha under the shield, emu and kangaroo.

Sources: www.itsanhonour.gov.au/coat-arms/index.cfm and www.anbg.gov.au/emblems/commonwealth-coat-of-arms.html, last accessed 13 March 2009.

Preserving the name Acacia exclusively for Australian species smacks somewhat of jingoism, inverse colonialism, or a sort. Australia is in a great position. It is a rich country with a well educated botanical public that can absorb name changes with a minimum of fuss...

Bruce Maslin denied that his push for retypification was 'just about jingoism' (Woodford 2002:1). In their response to Pedley, Maslin and Orchard said the 'emotive argument' about the loss of flat-topped trees of the African veldt was 'misleading', and dismissed his accusations, saying 'Such comments are inappropriate and serve no useful purpose and as such do not really warrant a response' (2004b:10-11).

Despite accusing each other of being jingoistic or emotive about the retypification issue, neither party wanted to acknowledge that no amount of justification regarding species numbers, grammatical inconveniences, or economic value could truly make a case for one side or the other. As Dick Brummitt (2010:1925) commented, 'there are strong practical (if not nomenclatural) arguments on both sides; the magnitude of changes required either way is unprecedented'. Hence, both sides invoked sentiments about euphonic, well-deserved names and placebased chauvinistic rhetoric to stand their ground and to gain the sympathy of non-scientific audiences. When the decision to retypify was passed in Vienna, the winners returned to their scientific high ground, saying that their case had been validated on rational criteria, while the opponents highlighted non-scientific biases in procedure, irrationality and unequal resources and power. As the altercations over acacia clearly reveal, not only is there tension in the science of classification, but sentiment - otherwise known as 'subjectivity' or 'irrationality' - played an 
important role in framing the arguments over the naming, labelling and reclassification of the genus. While Brummitt (2010) called them 'mere emotional outpourings', they have had no mere role in initiating and fuelling the conflict.

\section{Conclusion}

$\begin{array}{ll}\text { First Bruce: } & \text { This here's the wattle - the emblem of our land. You can stick it } \\ \text { All: } & \text { Amen a bottle or you can hold it in yer hand. }\end{array}$

The battles of Vienna and Melbourne reveal the welter of human sentiment that is invested in the name 'acacia'. More generally, they highlight the disgruntlements that can surface with each new scientific development in botanical taxonomy. They demonstrate how these feelings took on particular rhetorical forms in the acacia battles - about the euphony of words, senses of place, territorial chauvinisms and procedural and personal politics. Botanical nomenclature is much more than a set of rules and conventions; it reflects a particular institutional and ideological history about the classification and naming of plants, and it is permeated by sentiment. Although taxonomists say that the botanical nomenclature process accords names on the basis of objective rules, the reality, at least in the case of acacia, was far from being so. In the end, despite not being quite so simple or clear cut, the acacia name war was seen by many as an ambit by 'Australia' to claim the euphonic name acacia for its native wattles, with an outraged opposition, particularly 'African', defending the rules of priority to maintain acacia for its thorn trees.

Despite the decision in Vienna, several authors writing about African acacias have pointedly stuck with the broad genus name Acacia (e.g. Cameron 2006; Dharani 2006). Rupert Watson (2007:193) expresses the long-drawn resistance to altering the genus name Acacia in the acknowledgements to his book The African Baobab:

I end with a botanical footnote. I am well aware that Africa has lost the battle with Australia for the right to use the genus name of Acacia; however, I continue to use the old names for members of this genus, not through any sense of scientific stubbornness, but simply because these will continue in use in Africa for many years to come.

Watson's matter-of-fact assertion points to what Bowker and Star (1999:67-68) call the 'fault line' between scientific and folk classification. It is not a Great Divide, they say, but 'a fracture that is constantly being redefined and changing its nature as the plate of lived experience is subducted under the crust of scientific knowledge. This fault line is the ways in which temporal experiences - history, events, development, memory, evolution - are registered and expressed', by formal systems of classification. Taxonomic rules and procedures for naming plants may claim to be based on scientific objectivity and operate above the subjectivity of local and regional traditions, but they cannot avoid the sentiments of their own practising members. Taxonomists, it seems, are just as emotional as non-scientists when it comes to naming plants.

Debates surrounding the renaming of plants are bound to be fractious, messy and contradictory because of the experiences, memories and place-based sentiments that scientists, as people, and people as non-scientists (as 'folk' or 'community'), bring to the taxonomical

15 This proclamation, made by a stereotyped khaki-clad, knee-socked white bloke holding a wattle branch in bloom, features in an iconic sketch of Australia in the British comedy series, Monty Python, Episode 22 'How to recognise different parts of the body', filmed on 25 September 1970 and first aired 24 November 1970 (en.wikipedia.org/wiki/List_of_Monty_ Python's_Flying_Circus_episodes). 
exercise. Bowker and Star (1999:326) argue for flexible classifications 'whose users are aware of their political and organizational dimensions and which explicitly retain traces of their construction... The only good classification is a living classification'. We would echo their view by saying that the only good name is a living name. As Helmreich (2005:119) points out in the case of naming the algae species found around Hawaii, "it is ironic that, through oral traditions, the Hawaiian names have been perpetuated and usually accurately applied to the individual species, whereas three-fourths of the scientific names have been changed in the past 90 years'. The living scientific name for Acacia is Acacia in its broad sense, regardless of whether it is properly classified according to the rules of cladistics or any other system. ${ }^{16}$ This, in part, is why the acacia name change has generated such furore and emotion among members of the international botanical community and generated outpourings of sentiment among nonbotanists in Australia, Africa and many other parts of the world.

Brummitt $(2010,2011)$ noted that the unprecedented uproar over the acacia name required unconventional approaches to taxonomic rules so as to accommodate cases where particular plant names are associated with strong sentiments. While he suggests that bending the rules this one time would be 'unlikely to impact on other names in the future' (2010:1925), we suggest that aesthetic sentiments, territorial chauvinisms and personal agendas will always play a role in debates over classification and nomenclature. Molecular systematics has put many plant classifications, and hence names, under pressure, as have other scientific advances in the past and as others will no doubt do in the future. The crises that result, for acacia and other names, may only be truly resolved by finding ways to recognise and incorporate people's feelings for sounds, places and traditions in plant names - even in Latin names. Denying their importance by invoking the pretext of 'scientific objectivity' will only undermine the ability of the International Code of Botanical Nomenclature to serve as a universal system into the future.

\section{Acknowledgements}

We are grateful to various botanists interviewed for this piece for sharing their insights regarding botanical nomenclature and molecular systematics, and for engaging with us in enlightening discussions and correspondence. We thank Michelle Aitken for contributing interview material from South Africa, and the anonymous referees who provided useful comments and suggestions for revising the essay. As always, the errors and the opinions expressed remain our own.

\section{References}

Bailey, L.H. 1933 [1963]. How Plants Get Their Names. New York: Dover.

Bentham, G. 1842. Notes on Mimoseae, with a synopsis of species. London Journal of Botany 1:318-528.

Bentham, G. and Mueller, F. 1864. Flora Australiensis. London: Lovell Reeve and Co.

Bonneuil,C.2002.The manufacture of species: Kew Gardens, the Empire, and the standardisation of taxonomic practices in late nineteenth-century botany. In: Bourguet, M.-N., Licoppe, C. and Sibum, H.O. (eds), Instruments, Travel and Science, pp. 189-215. London: Routledge.

Bowker, G. and Star, S.L. 1999. Sorting Things Out: Classification and its consequences. Cambridge: MIT Press.

$16 \quad$ For instance, proponents of a 'phylocode' advocate a completely new way to organise botanical nomenclature (Foer 2005), while proponents of a new, information-technology based biology predict a revolution in research based on a new 'Global Names Architecture' (Patterson et al. 2010). 
Boy, G. 2005. The name of the acacia. Swara (East African Wildlife Society) 28(3):24-27.

Brenan,J.P.M. and Melville, R. 1960. The Latin name of the Black Wattle. Kew Bulletin 14:37-39.

Brockway, L.H. 1979. Science and Colonial Expansion. New York: Academic Press.

Brooker,M.I.H. and Kleinig, D.A. 2007. Field Guide to Eucalypts, 3rd ed.Melbourne: Bloomings Books.

Brown, G.K., Murphy, D.J., Miller, J.T. and Ladiges, P.Y. 2008. Acacia s.s. and its relationship amongst tropical legumes, tribe Ingeae (Leguminosae:Mimosoideae). Systematic Botany 33:739-751.

Browne, J. 1996. Biogeography and Empire. In: Jardine, N., Secord, J. and Spary, E. (eds), Cultures of Natural History, pp. 305-321. Cambridge: Cambridge University Press.

Brummitt, R.K. 2004. Report of the Committee for Spermatophyta: 55. Proposal 1584 on Acacia. Taxon 53(2):826-829.

Brummitt, R.K. 2010. Acacia: a solution that should be acceptable to everybody. Taxon 59(6):1907-1933.

Brummitt, R.K. 2011. Acacia: Do we want stability or total change? Taxon 60(3):915.

Cameron, B. 2006. We were conned! Veld and Flora March 2006, p. 51.

Carruthers, J. and Robin, L. 2009. Taxonomic imperialism in the battles for Acacia: identity and science in South Africa and Australia. Transactions of the Royal Society of South Africa 65(1):48-64.

Carruthers, J., Robin, L., Hattingh, J., Kull, C.A., Rangan, H. and van Wilgen, B.W. 2011. A native at home and abroad: the history, politics, ethics and aesthetics of Acacia. Diversity and Distributions. DOI:10.1111/j.1472-4642.2011.00779.x.

Clarke, H.D., Downie, S.R. and Seigler, D.S. 2000. Implications of chloroplast DNA restriction site variation for systematics of Acacia (Fabaceae: Mimosoideae). Systematic Botany 25(4):618-32.

Cook, H. 2005. Global economies and local knowledge in the East Indias: Jacobus Bontius learns the facts of Nature. In: Schiebinger, L. and Swan, C. (eds), Colonial Botany, pp. 100118. Philadelphia: University of Pennsylvania Press.

de Wildeman, É. 1925. Acacia mearnsii. Plantae Bequaertianae 3(1):61-62.

Dear, P. 2006. The intelligibility of nature. Chicago: University of Chicago Press.

Dharani, N. 2006. Field Guide to Acacias of East Africa. Cape Town: Struik Publishers.

Foer, J. 2005. What if we decide to rename every living thing on Earth? Pushing phylocode. Discover (discovermagazine.com/2005/apr/pushing-phylocode/).

Foster, S. and Johnson, R. 2006. Desk Reference to Nature's Medicine. Washington: National Geographic Society.

Githahu, M. 2006. Did you know it was illegal to call this tree acacia? Sunday Nation (Nairobi) June 25.

Glazewski, J. and Rumble, O. 2009. A rose is a rose but is an Acacia an Acacia? Global administrative law in action. Acta Juridica 9:374-394.

Gledhill, D. 2008. The Names of Plants. 4th ed. Cambridge: Cambridge University Press.

Hanelt, P., Schultze-Motel, J. and Jarvis, C.E. 1983. Proposal to conserve Triticum aestivum L. (1753) against Triticum hybernum L. (1753) (Gramineae). Taxon 32(3):492-498.

Helmreich, S. 2005. How scientists think; about 'natives', for example. A problem of taxonomy among biologists of alien species in Hawaii. Journal of the Royal Anthropological Institute NS 11:107-28.

Hoffman, L. 2006. Letter. Veld and Flora March 2006, p. 51.

Hoffmann, J. 2001. Golden wattle loses its lustre: biological control of Australian acacias in South Africa. Veld and Flora 87(2):58. 
Jobson, R.W. and Luckow, M. 2007. Phylogenetic study of the genus Piptadenia (Mimosoideae: Leguminosae) using plastid trnL-F and trnK/matK sequence data. Systematic Botany 32(3):569-75

Koerner, L. 1996. Carl Linnaeus in his time and place. In: Jardine, N., Secord, J.A. and Spary, E.C. (eds), Cultures of Natural History, pp. 145-162. Cambridge: Cambridge University Press.

Lafuente, A. and Valverde, N. 2005. Linnaean botany and Spanish imperial biopolitics. In: Schiebinger, L. and Swan, C. (eds), Colonial Botany, pp. 134-147. Philadelphia: University of Pennsylvania Press.

Luckow, M., Hughes, C., Schrire, B., Winter, P., Fagg, C., Fortunato, R., Hurter, J., Rico, L., Breteler, F.J., Bruneau, A., Caccavari, M., Craven, L., Crisp, M., Delgado, A., Demissew, S., Doyle, J.J., Grether, R., Harris, S., Herendeen, P.S., Hernández, H.M., Hirsch, A.M., Jobson, R., Klitgaard, B.B., Labat, J.N., Lock, M., MacKinder, B., Pfeil, B., Simpson, B.B., Smith, G.F., Sousa, M., Timberlake, J., van der Maesen, J.G., van Wyk, A.E., Vorster, P., Willis, C.K., Wieringa, J.J. and Wojciechowski, M.F. 2005. Acacia: the case against moving the type to Australia. Taxon 54(2):513-9.

Macey, R. 2005. Oh baby, look what the change in weather blew in. Sydney Morning Herald, September 2, 2005.

Maclaurin, J. and Sterelny, K. 2008. What is biodiversity? Chicago: University of Chicago Press.

Maslin, B.2003. Classification and phylogeny of Acacia: a synopsis http://www.worldwidewattle. com/infogallery/taxonomy/classification.php, last accessed 2008 December 18.

Maslin, B. 2011. Acacia and the IBC. Australian Systematic Botany Newsletter 146: 2-6.

Maslin, B. and Orchard, T. 2004a. Most Australian wattles likely to remain Acacia.Acacia Study Group Newsletter 92:5-7.

Maslin, B. and Orchard, T. 2004b. Response to Pedley's paper titled 'Another view of Racosperma'. Acacia Study Group Newsletter 93:7-12.

Maslin, B., Miller, J.T. and Seigler, D.S. 2003a. Overview of the generic status of Acacia (Leguminosae: Mimosoideae). Australian Systematic Botany 16:1-18.

Maslin, B., Orchard, A.E. and West, J.G. 2003b. Nomenclatural and classification history of Acacia (Leguminosae: Mimosoideae), and the implications of generic subdivision. www. worldwidewattle.com/infogallery/taxonomy/nomen-class.pdf, last accessed 7 June 2011.

McNeill, J. and Turland, N.J. 2010. The conservation of Acacia with A.penninervis as conserved type. Taxon 59(2):1-4.

Midgley, S.J. and Turnbull, J.W.2003. Domestication and use of Australian acacias: case studies of five important species. Australian Systematic Botany 16:89-102.

Miller, J.T., Grimes, J.W., Murphy, D.J., Bayer, R.J., \& Ladiges, P.Y. 2003. A Phylogenetic Analysis of the Acacieae and Ingeae (Mimosoideae: Fabaceae) based on trnK, matK, psbAtrnH, and trnL/trnF Sequence Data. Systematic Botany, 28(3):558-566.

Montgomery, K. 2006. Brand acacia goes to Australia. South African Gardening, July 2006, www. sagardening.co.za/forum/forums/thread-view.asp?tid=25@posts=3andstart=1, accessed 22 Nov. 2007.

Moore, A. 2006a. Economic and cultural pillage. Veld and Flora, March 2006, 51.

Moore, A. 2006b. Re-typing Acacia. Veld and Flora, June 2006:72-3.

Moore, G. 2007. The handling of the proposal to conserve the name Acacia at the 17 th International Botanical Congress - an attempt at minority rule. Bothalia 37(1):109-118.

Moore, G., Smith, G.F., Figueiredo, E., Demissew, S., Lewis, G., Schrire, B., Rico, L. and Van Wyk, A.E. 2010. Acacia, the 2011 Nomenclature Section in Melbourne, and beyond. Taxon 59(4):1188-1195. 
Moore, G., Smith, G.F., Figueiredo, E., Demissew, S., Lewis, G., Schrire, B., Rico, L., van Wyk, A.E., Luckow, M., Kiesling, R. and Sousa, M.S. 2011. The Acacia controversy resulting from minority rule at the Vienna Nomenclature Section: much more than arcane arguments and complex technicalities. Taxon 60(3):852-857.

Müller-Wille, S. 2005. Walnuts at Hudson Bay, Coral reefs in Gotland: The colonialism of Linnaean botany. In: Schiebinger, L. and Swan, C. (eds), Colonial Botany, pp. 34-48. Philadelphia: University of Pennsylvania Press.

Murphy, D.J. 2008. A review of the classification of Acacia (Leguminosae, Mimosoideae. Muelleria 26:10-26.

Murphy, D.J., Miller, J.T., Bayer, R.J. and Ladiges, P.Y. 2003. Molecular phylogeny of Acacia subgenus Phyllodineae (Mimosoideae: Leguminosae) based on DNA sequences of the internal transcribed spacer region. Australian Systematic Botany 16:19-26.

O'Neill, G.2007. Flowering flow of ideas leads to solving thorny questions. UniNews (University of Melbourne), 5-19 February 2007.

Orchard, A.E. and Maslin, B.R. 2003. Proposal to conserve the name Acacia (Leguminosae: Mimosoideae) with a conserved type. Taxon 52:362-3.

Orchard, A.E. and Maslin, B.R. 2005. The case for conserving Acacia with a new type. Taxon 54(2):509-12.

Parry, B.C. 2004. Trading the Genome: Investigating the Commodification of Bio-Information. New York: Columbia University Press.

Patterson, D.J., Cooper, J., Kirk, P.M., Pyle, R.L. and Remsen, D.P. 2010. Names are the key to the big new biology. Trends in Ecology \& Evolution 25: 686-691.

Pavord, A. 2005. The Naming of Names: The search for order in the world of plants. London: Bloomsbury.

Pedley, L. 1986. Derivation and dispersal of Acacia (Leguminosae), with particular reference to Australia, and the recognition of Senegalia and Racosperma. Botanical Journal of the Linnean Society 92:219-54.

Pedley,L.2003. A synopsis of Racosperma C.Mart.(Leguminosae:Mimosoideae).Austrobaileya 6(3):445-496.

Pedley, L. 2004. Another view of Racosperma. Acacia Study Group Nerwsletter 90:3-5.

Richmond, C.W. 1918. In memoriam: Edgar Alexander Mearns. The Auk: A Quarterly Journal of Ornithology 35(1):1-18.

Robin, L. 2002. Nationalising nature: wattle days in Australia. Journal of Australian Studies 73:13-26 and notes 219-23.

Robin, L. 2007. How a Continent Created a Nation. Sydney: UNSW Press.

Robin, L. 2008. Wattle nationalism. National Library of Australia Nerws, January 2008:3-6.

Ross, J.H. 1980. A survey of some of the pre-Linnean history of the genus Acacia. Bothalia 13(1 and 2):95-110.

Schiebinger, L. 1996. Gender and natural history. In: Jardine, N., Secord, J.A. and Spary, E.C. (eds), Cultures of Natural History, pp. 163-177. Cambridge: Cambridge University Press.

Schiebinger, L. 2004. Plants and Empire. Cambridge: Harvard University Press.

Schiebinger, L. and Swan, C. (eds), 2005. Colonial Botany. Philadelphia: University of Pennsylvania Press.

Scott, J. 1998. Seeing Like a State. New Haven: Yale University Press.

Seigler, D.S. and Ebinger, J.E. 2006. New combinations in the genus Vachellia (Fabaceae: Mimosoideae) from the New World. Phytologia 87:139-178.

Seigler, D.S., Ebinger, J.E and Miller, J.T. 2006: The genus Senegalia (Fabaceae: Mimosoideae) from the New World. Phytologia 88:38-93.

Smith, G.F., van Wyk, A.E., Luckow, M. and Schrire, B. 2006. Conserving Acacia Mill. with a 
conserved type. What happened in Vienna? Taxon 55(1):223-5.

Smith, B. 2011. Wattle it be? Name claim for Africa or Australia. The Age (Melbourne), July 25.

Soltis, D.E., Chanderbali, A.S., Kim, S., Buzgo, M. and Soltis, P.S. 2007. The ABC Model and its Applicability to Basal Angiosperms. Annals of Botany 100(2):155-163.

Spencer, R., Cross, R. and Lumley, P. 2007. Plant Names: A Guide to Botanical Nomenclature, 3rd ed. Melbourne: Royal Botanic Gardens and CSIRO Publishing.

Thiele, K.R., Funk, V.A., Iwatsuki, K., Morat, P., Peng, C.-I , Raven, P.H., Sarukhán, J. and Seberg, O. 2011. The controversy over the retypification of Acacia Mill. with an Australian type: a pragmatic view. Taxon 60(1):194-198.

Turland, N.J. 2011. A suggested compromise on the nomenclature of Acacia. Taxon 60(3) (online early).

van Rijckevorsel, P. 2006. Acacia: what did happen at Vienna? Anales del Jardín Botánico de Madrid 63(1):107-10.

Vassal,J. 1972. Apport des recherches ontogéniques et séminologiques à létude morphologique, taxonomique et phylogénique du genre Acacia. Bulletin de la Société d'Histoire Naturelle de Toulouse 108:105-247.

Watson, R. 2007. The African Baobab. Cape Town: Struik.

Webb, C.J., Sykes, W.R. and Garnock-Jones, P.J. 1988. Flora of Nerw Zealand. Volume IV: Naturalized Pteridophytes, Gymnosperms, Dicotyledons. Christchurch: DSIR.

Williams, R. 1980. Ideas of nature. In: Williams, R. (ed), Problems in Materialism and Culture, pp. 67-85. London: Verso.

Winston, J.E. 1999. Describing Species. New York: Columbia University Press.

Woodford, J. 2002. Wattle they call it? Icon with a name that came out of Africa. Sydney Morning Herald, November 9:9-10.

Yoon, C.K. 2009. Naming Nature: The Clash Between Instinct and Science. New York: WW Norton \& Company. 